\title{
A cross-cultural study of condolence strategies in a computer-mediated social network
}

\author{
Minoo ALEMI ${ }^{1}$, Niayesh PAZOKI MOAKHAR ${ }^{2}$ and Atefeh REZANEJAD ${ }^{3}$ \\ ${ }^{1}$ Islamic Azad University, West Tehran Branch \\ Tehran, Iran \\ ${ }^{2}$ Simon Fraser University \\ Burnaby, Canada \\ ${ }^{3}$ Allameh Tabataba'i University \\ Tehran, Iran
}

\begin{abstract}
Among the various speech acts, an under-investigated one is condolence speech act. The present study sought to investigate the verbal strategies of expressing condolence used by (1) Iranian native speakers of Persian, (2) Iranian EFL (English as a Foreign Language) learners, and (3) American native speakers of English. Accordingly, a total of 200, 42, and 50 responses were collected respectively from the informants who responded to an obituary post followed by a picture consisting of a situation related to the news of a celebrity's death on Instagram (In the case of Iranians: Morteza Pashaii, a famous singer \& in the case of Americans: B. B. King, an American singer-songwriter). After creating a pool of responses to the death announcements and through careful content analysis, the utterances by native Persian speakers, EFL learners, and native English speakers were coded into seven, nine, and seven categories, with expression of affection $(n=109,46.38 \%)$, wishes for the deceased $(n=34,59.64 \%)$, and wishes for the deceased $(n=32,23.70 \%)$ being the most prevalent ones, correspondingly. Moreover, tests of Chi-square revealed that there was a statistically significant difference among the three groups. The results showed that there were significant differences among the participants in terms of using condolence strategies in Expression of affection (love and grief), Wishes for the deceased, Expression of shock, use of address terms, expression of gratitude, Offering condolences, expression of happiness for his peaceful death, and Seeking absolution from God categories, with Expression of affection being the most prevalent one among Iranian Persian speakers. The findings have pedagogical implications for EFL teachers as wells as textbook and course designers.
\end{abstract}

Keywords: cross-cultural pragmatics, speech act, condolence, native speakers of Persian, native speakers of English, EFL learners

\section{For citation:}

Alemi, Minoo, Niayesh Pazoki Moakhar \& Atefeh Rezanejad. 2021. A cross-cultural study of condolence strategies in a computer-mediated social network. Russian Journal of Linguistics 25 (2). 417-442. DOI: https://doi.org/10.22363/2687-0088-2021-25-2-417-442 


\title{
Межкультурное исследование стратегий выражения соболезнования в социальных сетях
}

\section{МинУ АЛЕМИ ${ }^{1}$, НИяеш ПАЗОКИ МОАХАР ${ }^{2}$, Атефех РЕЗАНЕЖАД ${ }^{3}$}

${ }^{1}$ Западно-Тегеранское отделение Исламского университета Азад

\author{
Тегеран, Иран \\ 2 Университет Саймона Фрейзера \\ Бернаби, Канада \\ ${ }^{3}$ Университет имени Алламе Табатабаи \\ Тегеран, Иран
}

\begin{abstract}
Аннотация
Выражение соболезнования относится к числу недостаточно изученных речевых актов. Настоящее исследование нацелено на рассмотрение вербальных стратегий выражения соболезнования, используемых (1) иранцами - носителями персидского языка, (2) иранцами, изучающими английский язык как иностранный и (3) американцами - носителями английского языка. Было собрано соответственно 200, 42 и 50 реакций информантов на некрологи с последующим описанием ситуации, соотносимой с новостями о смерти знаменитости в Инстаграм (объекты исследования - известный иранский певец Мортеза Пашай, известный американский автор и исполнитель песен Би Би Кинг). После сбора реакций на сообщения о смерти был проведен их контент-анализ. Реакции носителей персидского языка, реакции иранцев, изучающих английский язык как иностранный, и реакции носителей английского языка были закодировны по семи, девяти и семи категориям, среди которых превалировали выражение любви $(n=109,46.38 \%)$, пожелания усопшему $(n=34,59.64 \%)$ и пожелания усопшему $(n=32,23.70 \%)$ соответственно. Проверка по критерию хи-квадрат показала, что между тремя группами наблюдались значительные статические расхождения по части использования следующих стратегий: Выражение любви и скорби, Пожелания усопшему, Выражение состояния шока, Использование форм обращения, Выражение благодарности, Выражение соболезнования, Выражение радости от того, что смерть была умиротворением, Просьба к Богу о прощении. Среди иранцев носителей персидского языка превалирующей стратегией было Выражение любви. Результаты исследования имеют педагогическую ценность для преподавателей английского языка как иностранного, а также авторов учебников и создателей учебных курсов.
\end{abstract}

Ключевые слова: кросс-культурная прагматика, речевой акт, соболезнование, носители персидского языка, носители английского языка, лица, изучающие английский язык как иностранный

\section{Для цитирования:}

Alemi M., Pazoki Moakhar N., Rezanejad A. A cross-cultural study of condolence strategies in a computer-mediated social network. Russian Journal of Linguistics. 2021. Vol. 25. № 2. P. 417-422. DOI: https://doi.org/10.22363/2687-0088-2021-25-2-417-442

\section{Introduction}

In recent decades, cross-cultural pragmatics, the study of similarities and differences in cultural norms for producing utterances, has been in the limelight in the domain of applied linguistics (Blum-Kulka 1991, Kasper \& Dahl 1991). As Vygotsky (1978) puts it, learning and sociocultural interactions are tightly 
interrelated. Accordingly, social and cultural communications can influence the academic achievement and language performance of the language learners (Block 2007, Palovskaya \& Lord 2018). Furthermore, cultures vary greatly in their interactional styles and this will lead to inclinations in opting for different styles of speech act behavior and bring to light the importance of appropriateness of speech.

This issue further extends to the realm of Computer-mediated Communication (CMC) which is considered to be any type of communication that happens between people through some kinds of electronic devices and is very widespread nowadays. It can indeed enhance both the quantity and quality of interactions and further assist second language learners to practice language functions more practically (AbuSeileek 2013, Ajabshir 2019). The significance of CMC mostly lies in its capability in eliminating the geographical barriers to international communication which are mainly caused due to distance. To put it differently, thanks to the internet and its more pervasive availability, more and more people around the world are able to communicate with each other. However, an important point to bear in mind is that different countries and cultures around the globe have their own specific cultural norms and not observing these norms may lead to miscommunications among interlocutors. In the same way, for a second language learner the difficult task would be to learn the target language within this framework of constraints and norms and accordingly use apt verbal utterances to observe different speech acts. Due to the significance of the issue, the current study aimed to examine the verbal expressions used by Iranian native speakers of Persian, American native speakers of English, and Iranian EFL learners with regard to the speech act of condolence.

\section{Literature review}

\subsection{Theoretical background}

Pragmatics is generally defined as "the study of how to say what to whom and when" (Bardovi-Harlig 2013: 68). According to Shively (2010), pragmatics refers to the knowledge and skills which are necessary in order to use and interpret the meanings, conventions, and activities expressed by language in its socio-cultural perspective. By studying the field of pragmatics, learners can be engaged in learning different types of discourse and sharing the speech events with different complexity and length (Kasper \& Rose 2001, Taguchi 2011). Pragmatic competence refers to the ability to achieve a multidimensional interplay of language, language users, and context of communication (Taguchi 2011) along with the capability of using language efficiently so as to achieve a specific goal and to comprehend language in context (Thomas 1983).

This concept was further highlighted in Bachman's (1990) model of communicative competence which emphasized the appropriate use of language in different situations. Accordingly, appropriate use of speech acts (Austin 1962) can assist the accomplishment of this mutual understanding. That is why recently researchers have shifted their attention from grammatical competence to communicative competence and many studies have been conducted to investigate 
the performance of various speech acts around the world and by speakers of different languages.

The theory of speech acts was first introduced by J. L. Austin from Britain and later developed by the American philosopher John R. Searle. In fact, speech acts embody an extensive range of functions, some examples of which include apology, compliment and compliment response, request, refusal, invitation, and expression of sympathy. As Yule (1996) puts it, speech acts are defined as some set of speech functions which can be comprehended by words. Yule (1996) states that one of great social skills would be knowing when to say to the right thing to different people and also associates speech acts with the expression illocutionary acts, both of which emphasize the idea of communication behind utterances.

Moreover, different scholars have devised their own classifications of speech acts. Maybe one of the most well-known taxonomies is developed by Searle (1999) who classified speech acts into five groups, namely: assertive, directives, commisives, expressives, and declarations. As Searle (1999) points out, speech act of condolence can be categorized in the expressive group, since it is used to show and express the speaker's grief at someone's death. According to Yahia (2010), condolences are considered to be some formal statements used to sympathize with the family of the deceased. Also, as Mwihaki (2004) points out, condolences have their own social meaning and are used to fulfil a set of specific roles and relations in the society.

\subsection{Previous studies}

Death and its related events cannot be avoided in one's life and at times one may be forced to talk to someone who has recently lost a family member or friend. The point is that, if both interlocutors are from the same language or cultural background, there seems to be no problem. However, choosing the right words or actions regarding this sensitive speech act might turn into a big deal when the speaker and hearer are from different cultural backgrounds or languages (Wakefield, Chor \& Lai 2020). Due to the delicate nature of the condolence speech act, fewer studies have considered this speech act in comparison with the other speech acts such as compliment, refusal, or request. This might stem from the difficulties in collecting natural data concerning someone's death as well as sociocultural issues attached to the concept of death - some cultures even believe talking about death is a taboo (Parkes 2015, Wakefield, Chor \& Lai 2020). In this section, some of the most recent studies with regard to the speech act of condolence is presented.

One of the earliest studies on the speech act of condolence was conducted by Elwood (2004). It focused on the comparison of the realization of condolence speech act among native American students, Japanese EFL learners, and native Japanese speakers on two different suggested situations. The results indicated that many differences could be observed between the American and the Japanese students in their condolence productions. Also, in the EFL context of Iran, 
Pishghadam and Morady Moghaddam (2012) examined the cross-cultural dissimilarities between native English and Persian speakers with regard to responses to condolence. The data were collected through some movies and the responses that native speakers of Persian and English used when someone sympathized with them were observed. The results indicated that generally seven categories were used, namely (1) token of appreciation; (2) expressing sorrow; (3) sharing feeling; (4) comment on the deceased; (5) topic avoidance; (6) self-blame statement; and (7) divine comment. Their results also showed that there were significant differences between the observed groups.

Abdul-Majid and Salih's (2019) study focused on the cross-cultural differences in condolence strategies between Iraqi EFL learners and native English speakers from Australia. More specifically, it aimed to observe the Iraqi EFL learners' pragmatic ability. The data were collected through DCTs from three groups of participants: (1) Iraqi EFL learners; (2) Australian native speakers of English; and (3) Iraqi native speakers of Arabic. The results of their study proved the existence of pragmatic transfer and failure among the Iraqi EFL learners and also indicated that religion had a great impact on the type of used condolence strategies. Furthermore, Wakefield, Chor, and Lai's (2020) ethnographic study investigated the linguistic and cultural realization of death-related condolences among Cantonese and English speakers. Condolences that were offered to someone who has lost a close friend were collected through discourse completion tasks (DCTs). The results of their study mainly showed that "Anglo-English condolences typically focus on expressing that the condoler feels sad because of the bereaved's loss, while Cantonese condolences typically focus on telling the bereaved not to be sad and to take care of his-or herself" (p. 35). Also, Utama and Ariatmi's (2020) descriptive qualitative study examined 77 condolence messages posted in the social media after the death of Kobe Bryant (the basketball star) and his daughter. The results indicated that overall nine condolence strategies were used: (1) acknowledgment of the death, (2) expression of sympathy, (3) future oriented remarks, (4) seeking absolution from God, (5) related questions, (6) expressions of empathy, (7) statements of lacking words, (8) religious oriented sympathy, and (9) combination strategy. It was also found that expression of sympathy and seeking absolution from God were the most dominant strategy types.

\section{The present study}

A review of the previous studies in the literature illustrates that the speech act of condolence is still an under-researched area and deserves more attention, especially in the EFL context of Iran. Therefore, in this study, the offering of deathrelated condolences has been investigated among Iranian native speakers of Persian, American native speakers of English, and Iranian EFL learners in the context of social media (Instagram). Accordingly, the following research questions were put forth: 
1. What strategies do native speakers of Persian, native speakers of English, and Iranian EFL learners employ to produce the speech act of condolences in a computer-mediated social network?

2. Is there any significant difference in the strategies used by native speakers of Persian, native speakers of English, and Iranian EFL learners in their production of the speech act of condolences in a computer-mediated social network?

\section{Method}

\subsection{Participants}

The participants of this study included three groups. The first group were 200 female and male native speakers of Persian who responded to an obituary post followed by a picture with regard to the occasion on the social network of Instagram. They were selected based on convenience sampling.

The second group were 50 native speakers of English from both genders. These participants responded to an obituary post accompanied by a picture specific to that occasion updated on Instagram. These participants were form the United States of America and were selected based on convenient sampling. It also needs to be noted that as Instagram is a worldwide medium, the participants' age, gender and educational background were not observed. However, the personal profile of the selected responses were separately checked and we made sure that the person was from the United States. In fact we must admit that the data is currently based on the available information and we could only assume that people were honestly stating their nationality.

The third group included 48 (25 female and 23 male) intermediate and advanced EFL learners (their level of proficiency was reported by the language institute in which the data were collected). These participants responded to a hypothetical status accompanied by a picture through a task designed by the researcher. The task sought to elicit the speech act of condolence. These EFL learners responded to obituary status written in English but related to Persian figures.

\subsection{Data collection}

The elicitation tasks in this study included an Instagram-based corpus of a set of condolence comments posted on this social network by Persian and American native speakers. Another set of condolences came from the responses that Iranian EFL learners produced for the task devised by the researchers in an attempt to elicit condolence responses. These comments provided the researcher with the required corpus to explore the Persian condolence strategies used for Morataza Pashaii's (a celebrated Iranian singer) demise. It needs to be noted that these responses, were all in Persian. In this regard, a total number of 200 responses in Persian were identified. Another set of comments dealt with English comments produced by 
English Speakers. A total of 50 English comments to express condolences for B. B. King's (American singer-songwriter) death were collected through Instagram networking program. The third set of comments were 42 English comments produced by Iranian EFL learners. These comments were collected by providing the Iranian EFL learners with a task which elicited condolence responses for Morteza Pashaii's death announcement.

\subsection{Data Analysis}

This research was a type of corpus-based analysis which is the study of language as expressed in samples (corpora). Both quantitative and qualitative analyses of the corpus were taken into account. In the qualitative phase, a sample of corpus was selected randomly and the types of condolence strategies employed by the participants were identified. The random selection of the sample at this stage was solely for the purpose of getting familiar with the data and the classification scheme.

Then, based on the identified strategies, the classification scheme was used to identify the number and type of strategies used throughout the corpus. To ensure the reliability of the classification scheme, a research assistant was employed. The research assistant held a Ph.D. in TEFL and independently analyzed and codified the strategies participants used in responding to obituaries. After doing the analysis, the matches and mismatches among the researchers and the aforementioned research assistant were calculated. In this regard, Holsti's (1969) coefficient of reliability was utilized which shows the number of matches and agreements in the total number of ceded items. The observed value in this study was 0.87 , which is a sign of an excellent agreement and showed that that the inter-rater's coding results were consistent.

Next, two M.A. holders in TEFL were invited to cooperate. The classification scheme was given to the M.A. holders and they were instructed on how to identify the strategies. They were also told that in case they encountered any unidentified strategies they needed to consult the researcher. They identified the condolence strategies and counted the frequency of each strategy and no case of unidentified strategies were reported. Finally, the frequency counts of condolence strategies were fed into SPSS and Chi-Square was run to find any possible significant difference between the participants' productions.

\section{Results}

\subsection{Results of research question one}

The first research question dealt with the kind of strategies native speakers of English, native speakers of Persian, and Iranian EFL learners employ to produce the speech act of condolences in a computer-mediated social network. After creating a pool of responses to the death announcement status of popular people for the groups of the study, the utterances by native Persian speakers were coded into 
seven categories, EFL learners into nine categories, and American native speakers into seven categories.

\subsubsection{Native Persian speakers}

As can be seen in Table 1, the most frequent condolence strategy employed by native Persian speakers was Expressing affection $(n=109,46.38 \%)$. Also it was observed that the least frequent one was Offering condolences which was produced only once $(0.42 \%)$ by native Persian speakers. The findings are also depicted in Figure 1.

Table 1

Condolence Strategies used by Native Persian Speakers

\begin{tabular}{|c|l|c|c|}
\hline \multicolumn{1}{|c|}{ Type of condolence strategies } & Frequency & Percentage \\
\hline 1 & Expression of affection (love and grief) & 109 & $46.38 \%$ \\
\hline 2 & Wishes for the deceased & 45 & $19.14 \%$ \\
\hline 3 & Expression of shock & 42 & $17.87 \%$ \\
\hline 4 & Use of address terms & 27 & $11.48 \%$ \\
\hline 5 & Allusion to religious and metaphoric concepts & 6 & $2.55 \%$ \\
\hline 6 & Expression of gratitude & 5 & $2.12 \%$ \\
\hline 7 & Offering condolences & 1 & $0.42 \%$ \\
\hline
\end{tabular}

In the strategy Expression of affection (love and grief), people show their grief by stating how sad and depressed they are for losing the person. Table 2 presents some excerpts regarding this category of strategies accompanied with their English translations. As depicted, all the statements express some state of sadness and grieving and also the fact that people really loved the dead celebrity. This finding may be due to cultural issues specifically among Iranian people. Iranians are considered to be very emotional people, and this is much more evident when giving condolences. Therefore, the first thing which may come to mind when an Iranian is hearing about sad news seems to be a display of personal affection, to show how sad the person is. It is worth mentioning that giving condolence is essentially polite and is connected with positive illocutionary force. It is further related to "behabitives" and "expressives" in Austin and Searle's classifications, respectively. In fact, interlocutors use this speech act to express their feelings and attitudes.

Table 2

Examples of Expressing Affection (love and grief) Produced by Native Persian speakers

\begin{tabular}{|c|c|c|}
\hline & Persian & English translation \\
\hline 1 & 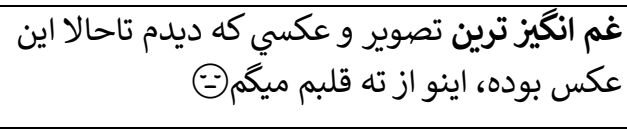 & $\begin{array}{l}\text { It was the most depressing picture (the posted } \\
\text { picture of the deceased person) I have ever } \\
\text { seen. I say this from the bottom of my heart. }\end{array}$ \\
\hline 2 & يك يه سال جه جورى كذشت بدون تو & How one year passed since your demise. \\
\hline 3 & دل دنياروخون كردى كه اينجورى تورفتى & $\begin{array}{l}\text { By your demise you made all of us extremely } \\
\text { sad. (referring to one of his songs) }\end{array}$ \\
\hline 4 & 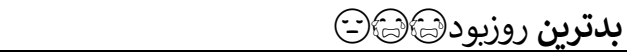 & The worst day (the day he died) \\
\hline
\end{tabular}




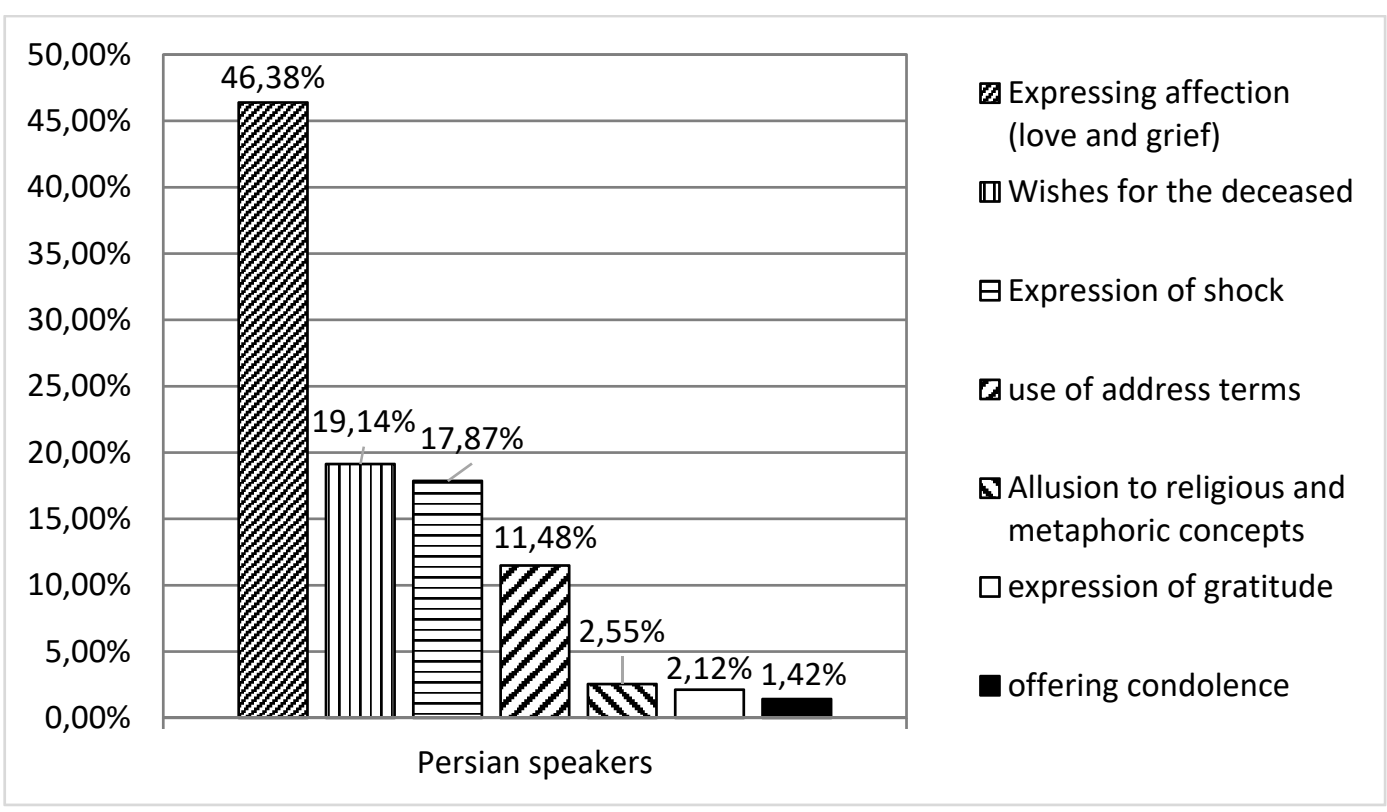

Figure 1. Percentage of Condolence Strategies among Native Persian speakers

Next, the strategy of Wishes for the deceased was the most frequent one with a frequency count of $n=45(19.14 \%)$. In this category, people made good wishes for the dead as well as wishing that he was still alive and among the society and the fans. Table 3 illustrates some examples of this category of strategies used by Persian speakers with the English translations. Statements in the examples clearly show that people made good wishes for the spirit of the person and, as the last example shows, people also wished that the dead person was still alive and among them. These comments are in fact extensively rooted in the Iranian Islamic culture, as this is a common act to wish peace and mercy form God for the dead person.

Table 3

Wishes for the Deceased Person and the English Translations

\begin{tabular}{|c|c|c|}
\hline & Persian & English translation \\
\hline 1 & روحش شاد و قرين رحمت و آرامش ابدى.. & $\begin{array}{l}\text { Wishing you happy spirit and be in everlasting } \\
\text { peace }\end{array}$ \\
\hline 2 & اميراطورم يك سالكى آرامشت مباركى & $\begin{array}{l}\text { My emperor, happy the first anniversary of your } \\
\text { peace }\end{array}$ \\
\hline 3 & بيا و بركرد & Come back please \\
\hline 4 & خدا رحمتش كنه واقعا جاش خاليه & $\begin{array}{l}\text { May God have mercy on him and we really miss } \\
\text { him (the dead person) }\end{array}$ \\
\hline
\end{tabular}

The next category of condolence strategy was Expression of shock $(n=42,17.87 \%)$ which conveys the fact that people are in a state of shock after the death of the person. Table 4 shows the examples of this category of strategies with the English translations. These statements show that people are still in shock and do not like to believe that the person is dead. This act might be due to the deep 
feelings that people had for the deceased person. Additionally, this singer was admired and revered a lot in Iran. He was also very young. These facts led to the experienced shock among people in response to his death.

Table 4

Examples of Expression of Shock and their English Translation

\begin{tabular}{|c|c|c|}
\hline & Persian & English translation \\
\hline 1 & نه نه دروغه & NO, NO, It's a lie (referring to his death) \\
\hline 2 & باور نمى كنم & I won't believe it (referring to his death) \\
\hline 3 & ن & No, No, No (showing disbelief) \\
\hline
\end{tabular}

Use of address terms was the next category with a frequency count of $n=27(11.48 \%)$. In this category, people expressed their sadness, grief, shock, and wishes but the difference is that in this category of condolence strategy, people made direct address to the deceased person, in this case Morteza (the first name of the deceased person). Table 5 displays some examples from this category. It should be pointed out that addressing terms are important communication tools which are extensively used in society. These address terms vary according to the gender, profession, social class, politeness and many other related features. People use address terms to actively involve the other person in the conversation. Using a direct address terms such as calling the first name of a person can only show how willing a person might be in having a friendly talk. It seems that the people in the current study called the first name of their favorite dead singer to show how much they loved him.

Table 5

Examples form the Category of Use of Address Terms

\begin{tabular}{|c|c|c|}
\hline & Persian & English translation \\
\hline 1 & 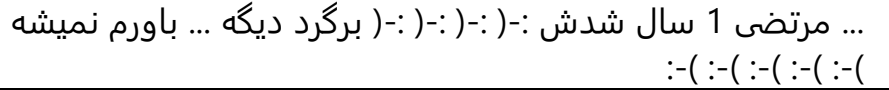 & $\begin{array}{l}\text { Morteza, It has been a year, } \\
\text { come back, I won't believe it. }\end{array}$ \\
\hline 2 & مرتضى & Morteza, My dear \\
\hline 3 & آقا مرتضى دلمون تركيييييد، تورو خدا برگرد & \begin{tabular}{|l} 
Morteza, I cannot tolerate \\
your loss. Please come back.
\end{tabular} \\
\hline
\end{tabular}

The next category of condolence strategy was Allusion to religious and metaphoric concepts which had a frequency count of $n=6(2.55 \%)$. In this category, frequent reference was made to religious ideas. For instance, in Iran it is quite common to say Salawat (اللهم صل على محمد وآل محمد) in religious, burial, and mourning ceremonies which is translated to O Allah: (please do) bless Muhammad and the Household of Muhammad. Reference to religious ideas was made in response to hearing about Morteza (the deceased person) among the various utterances made by Persian speakers. Table 6 displays some examples of this category of condolence strategies. The statements in the examples contain concepts that are mainly rooted in Iranian Muslim community. For instance, concepts such 
as "Fatihah" and "resurrect with Imam Hossein" (the third Shiite religious Imam among Shiite people), have roots in the Iranian Shiite community.

Table 6

Examples of Allusion to Religious and Metaphoric Concepts Produced by Native Persian Speakers

\begin{tabular}{|c|c|c|}
\hline & Persian & English translation \\
\hline 1 & 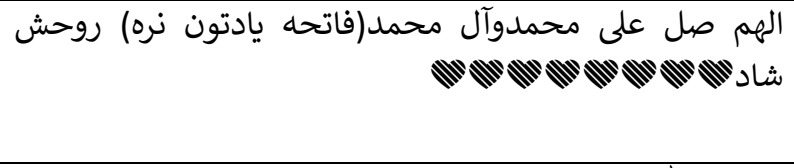 & $\begin{array}{l}\text { O Allah: (please do) bless } \\
\text { Muhammad and the Household of } \\
\text { Muhammad (do not forget to recite } \\
\text { Fatihah). Happy spirit }\end{array}$ \\
\hline 2 & ان شاء الله با حسين (ع) محشور بشى ----- & $\begin{array}{l}\text { Hope you would resurrect with } \\
\text { Imam Hossein. }\end{array}$ \\
\hline 3 & 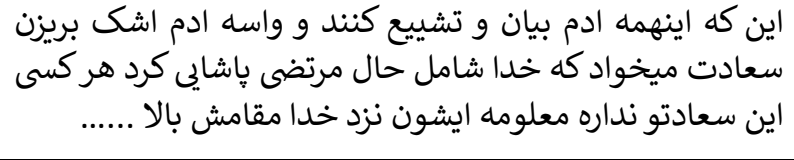 & $\begin{array}{l}\text { When there are many people } \\
\text { mourning for Morteza, it means } \\
\text { that he has such great position by } \\
\text { the God }\end{array}$ \\
\hline
\end{tabular}

The next category was Expression of gratitude which had a frequency count of $n=5(2.12 \%)$ and strategies within this category included statements that showed people were thankful for his works. Some related condolence examples can be found in table 7. The statements clearly show that people adore this singer for his great works and his personality. In fact, it is a common saying that expressing gratitude and being thankful can make you calm and bring a sense of happiness and satisfaction. Also, through showing gratitude one can be polite. Expressing gratitude is truly a sign of appreciation and concern. In the same way, the Iranian participants in the present study tried to show this gratitude and care through words and by remembering how superb their favorite singer was.

Table 7

Examples of expression of gratitude as way of expressing condolence by native Persian speakers

\begin{tabular}{|c|c|c|}
\hline & Persian & English translation \\
\hline 1 & عالى بودى مرتضى جان يادت گرامى & $\begin{array}{l}\text { You were perfect, I always remember you with } \\
\text { respect }\end{array}$ \\
\hline 2 & مرتضى عزيز بى نظير بودى & You were unique \\
\hline 3 & تا هميشه بهترين خواننده من ميمونى & You will be my best singer forever \\
\hline
\end{tabular}

The last strategy used by native Persian speakers as a way for expressing condolence was Offering condolences which was produced only once. In this strategy people simply express their condolence without adding any metaphoric or any utterance to flavor and color the main condolence statement. The only example of this strategy was the utterance [سليت ميكحم] which is translated into English as I extend my condolence. The low frequency of this type of condolence might be due to the fact that in Persian longer condolence is considered more polite and seems more realistic. Expressing condolence by a simple offering of condolence may not seem very appropriate. Therefore, we didn't find many condolences of this category. 


\subsubsection{English speakers}

Based on the frequency count of data and as depicted in Table 8 (Figure 2), the most frequent condolence strategy produced by native English Speakers in a computer mediated social network was Wishes for the deceased $(n=32,23.70 \%)$ and the least frequent one was Seeking absolution from God $(n=3,2.22 \%)$. Wishes for the deceased strategy included statements about wishing peace and good afterlife for the deceased. What follows are some examples from this condolence strategy by English Speakers for the death of Riley B. King, known professionally as B. B. King.

- Rest in peace Mr. King! Know you are in heaven entertaining the angels!

- Glad to hear he went peacefully. Rest in Peace, I hope they bury Lucille with him.

- Rest in heavenly peace, my King [heart emoticon].

Table 8

Condolence Strategies Used by Native English Speakers

\begin{tabular}{|c|l|c|c|}
\hline \multicolumn{1}{|c|}{ Type of condolence strategies } & Frequency & Percentage \\
\hline 1 & Wishes for the deceased & 32 & $23.70 \%$ \\
\hline 2 & Use of address terms & 27 & $20 \%$ \\
\hline 3 & Expression of gratitude & 23 & $17.03 \%$ \\
\hline 4 & Expression of affection & 19 & $14.07 \%$ \\
\hline 5 & Express happiness for his peaceful death & 4 & $2.96 \%$ \\
\hline 6 & Seeking absolution from God & 4 & $2.96 \%$ \\
\hline 7 & Expression of condolence & 1 & $0.74 \%$ \\
\hline
\end{tabular}

The above statement clearly conveys good wishes for the deceased person (Mr. King). Phrases like Rest in peace and I hope ... are the starting phrases which indicates making a wish for the deceased. The next frequent strategy used by the native English Speakers was the Use of address terms $(n=27,20 \%)$. In this category, English Speakers explicitly mentioned the name or the title of the deceased person in extending condolences. The content of the condolences may be similar to the content of other types of condolences like the expression of gratitude or affection. Following are some examples of this condolence category:

- R.I.P. B.B. King. You will be missed by the WHOLE WORLD.

- Long Live Mr. B.B. King!!

- Mr. B.B. King you will be missed but we will keep you alive listening to you music. R.I.P.

- Mr. King, thank you for your music and your words. You certainly made an impact on me and millions of others that will go on and on. You are a legend and will be missed. Rest in peace.

Examples explicitly contain the name of the deceased person along with the expression of affection as in the first and third examples, offering good wishes as in the second example and showing gratitude as in the fourth one. 


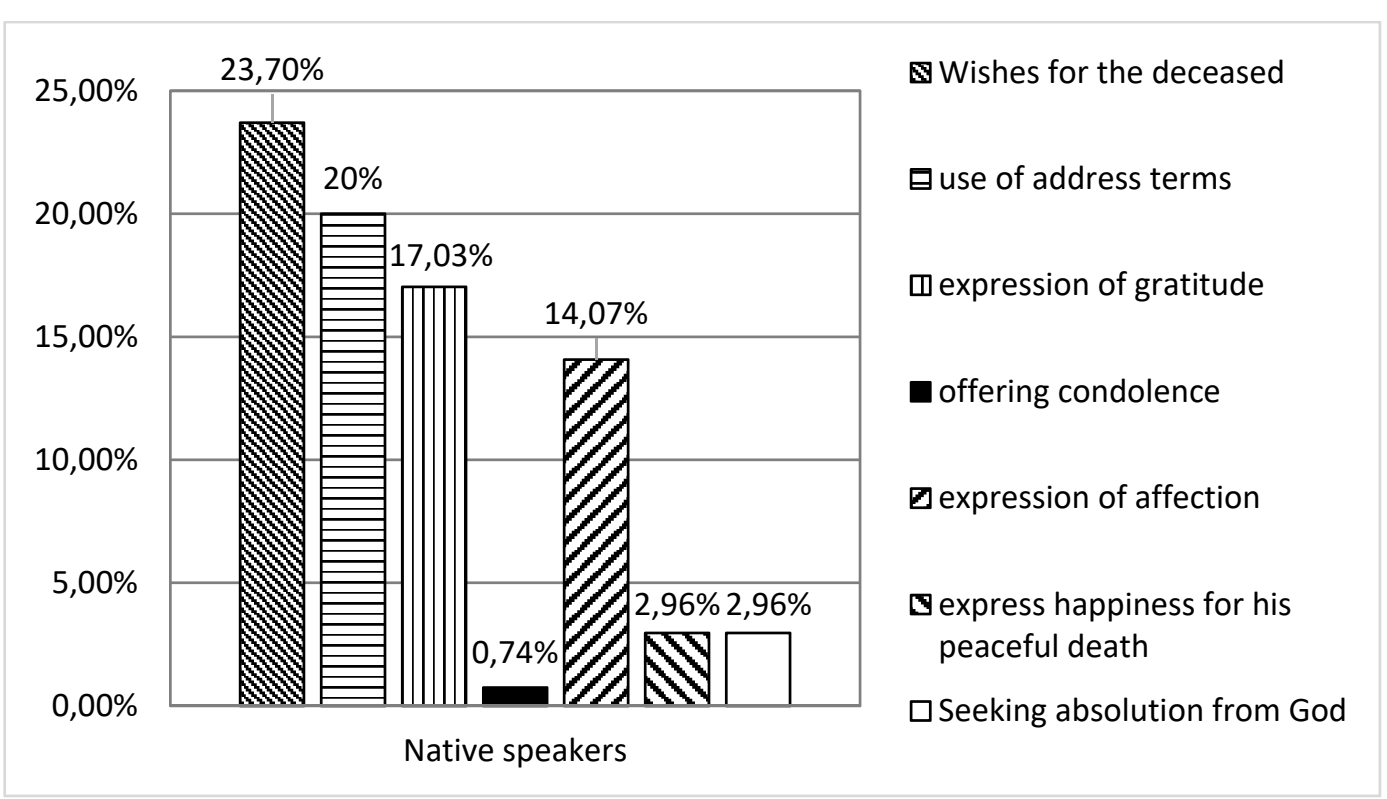

Figure 2. Percentage of condolence strategies among native English speakers

Expression of gratitude was the third frequent category of condolence strategies by Native English speakers and had a frequency count of $n=23(17.03 \%)$. As the name speaks, this category dealt with utterances that expressed thankfulness for Mr. Kings' great works. In what follows, some examples from this category are presented:

- What a wonderful legacy you have left for the world.

- Your legacy lives on! Job well done!

- Thank you for the decades of music you have blessed us with.

The fourth category of condolence strategy by the native English Speakers was the Epression of ffection $(n=19,14.07 \%)$. In this category American people indicated their feeling and affection toward the deceased (Mr. King). Some examples are as follows:

- Gone, but he'll never be forgotten.

- The Blueset Man And Idiol Of Mine Since I've Been In Music.......... And I You Will Always Be IN My Heart And Soul

- Hole in my heart today and tears on my cheeks. RIP Mr. King. You are gone from us but never forgotten. What a wonderful legacy you have left for the world.

The above samples clearly show that some people liked to express their feeling for Mr. King as he was loved by so many Americans. Moreover, Expression of happiness for his peaceful death and Seeking absolution from God were the two next most frequent condolence categories, both occurring 4 times $(2.96 \%)$. In fact, the former deals with the fact the people are happy for his peace after death and the latter deals with statements that ask for Mr. King's forgiveness from God and God's 
Mercy. In the following examples, the first two examples are from the category of Expression of happiness for his peaceful death and the last two examples are from the category of Seeking absolution from God.

- Glad to hear he went peacefully. Rest in Peace, I hope they bury Lucille with him.

- Hard to like this post! But what I like is that he "passed peacefully in his sleep". He deserved this! RIP Riley!

- .......God bless Mr. King... he forever changed the way the ......

- ...God Be With You ....

Finally, the last category which was the least frequent condolence strategy was the expression of condolence which was observed only once $(0.74 \%)$ by the Native English speakers. In this category, a statement of condolence was simply expressed. The only instance of this category was Offer condolences to his family which did not contain any external statement for praising, loving, or thanking. This may of course be due to cultural issues. It seems that longer condolence expressions seem more polite and real. People try to show how sad they are at the loss of their favorite singer and this is mostly observed by using more words and expressions when giving condolence.

\subsubsection{EFL Learners}

In a similar vein, various condolence strategies produced by Iranian EFL learners were counted and rank ordered (see Table 9 \& Figure 3). As depicted below, the most frequent condolence strategy produced by the Iranian EFL learners in a computer mediated network was Wishes for the deceased and the least frequent strategies were Statement about life and death and Expression of shock equally. Wishes for the deceased had a frequency count of $n=34(59.64 \%)$ and both Statement about life and death and Expression of shock were equally produced only once $(1.75 \%)$ by the Iranian EFL learners.

Table 9

Condolence Strategies Used by Iranian EFL Learners

\begin{tabular}{|c|l|c|c|}
\hline \multicolumn{1}{|c|}{ Type of condolence strategies } & Frequency & Percentage \\
\hline 1 & Wishes for the deceased & 34 & $59.64 \%$ \\
\hline 2 & Expression of affection (love and grief) & 6 & $10.52 \%$ \\
\hline 3 & Expression of gratitude & 6 & $10.52 \%$ \\
\hline 4 & Use of address terms & 4 & $7.01 \%$ \\
\hline 5 & Offering condolences & 3 & $5.38 \%$ \\
\hline 6 & Expression of sarcasm & 2 & $3.50 \%$ \\
\hline 7 & Statement about life and death & 1 & $1.75 \%$ \\
\hline 8 & Expression of shock & 1 & $1.75 \%$ \\
\hline
\end{tabular}

Similar to the same strategy produced by the native English and Persian speakers, in the category of Wishes for the deceased, people made good wishes for 
the deceased person and his soul in afterlife. What follows are some examples of this category of condolence strategy produced by Iranian EFL learners:

- God bless him

- May his soul Rest in peace

- Rest in peace and god bless you

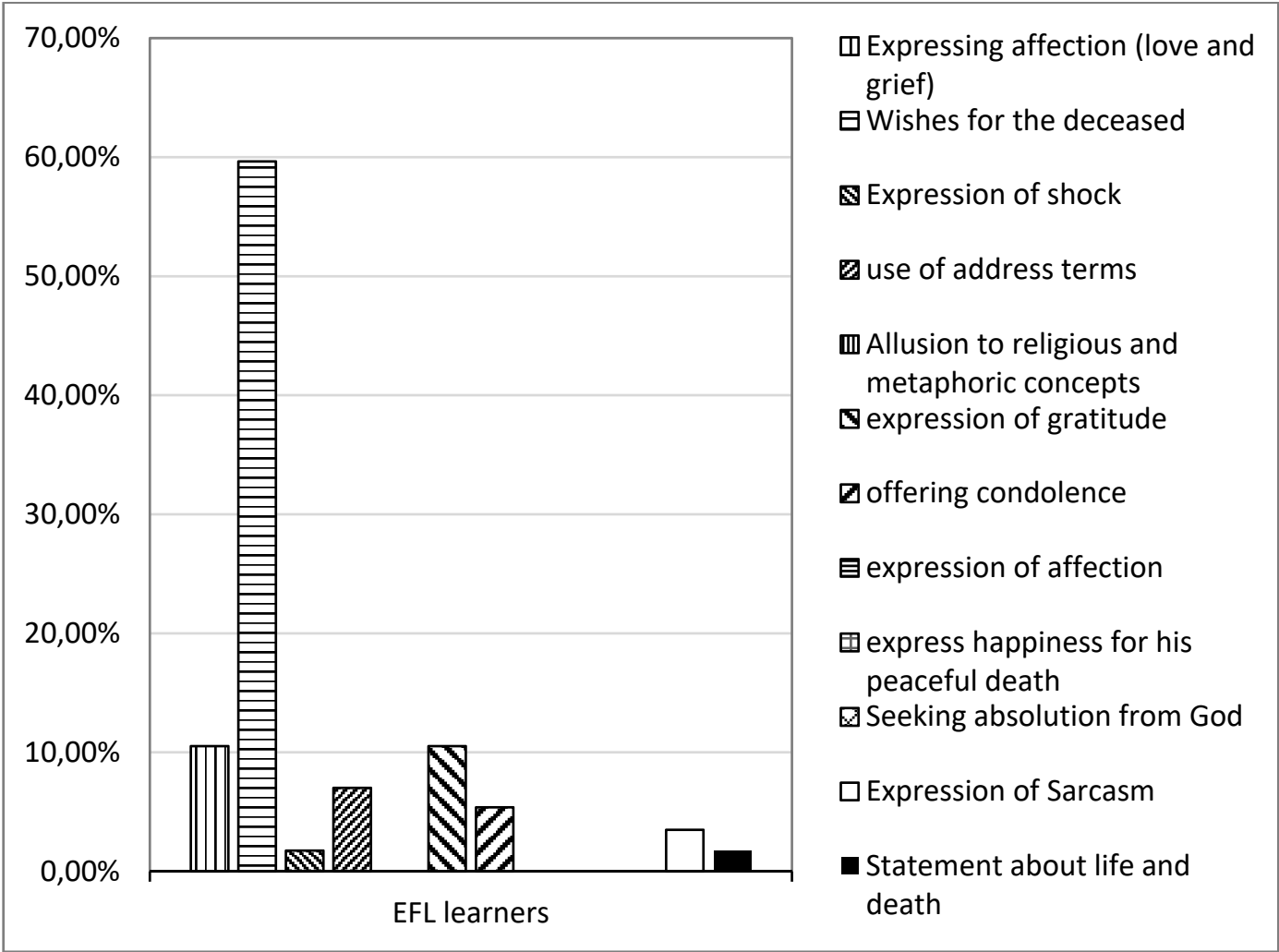

Figure 3. Percentage of condolence strategies among EFL learners

The next frequent condolence strategy by the Iranian EFL learners was Expressing affection (love and grief) which was similar in content to the same strategy used by native English speakers and native Persian speakers. This strategy had a frequency count of $n=6(10.52 \%)$ and, as stated earlier, people in this category of condolence strategy show their feelings and affections toward the deceased person. Some relevant examples are as follows:

- You're always in our hearts!

- I can't cry for enormous pain, I should just tolerate and dye (die) step by step

Similarly, the category of Expression of gratitude occurred 6 times (10.52\%). In this category people also use statements that convey respect and thankfulness for the deceased person because of his valuable works during his life. Here are some examples of this category: 
- It is really soon! I'll never forget U my favorite singer! We miss you... .

- I get repose when I hear your voice

Use of address terms was the fourth category in terms of frequency count. This condolence strategy had a frequency count of $n=4(7.01 \%)$ and people explicitly used the name of the deceased person in their condolence expressions. Following are two examples of this category:

- Rest in peace dear Morteza

- Rest in Peace MORTEZA PASHAEEI

As the examples clearly demonstrate, the name of the deceased person (Morteza) is seen in the condolence statements. The content of the condolences does not vary very much from other condolence strategies and the only observed difference was the explicit use of the name of the deceased person.

The next condolence strategy was offering condolences which was produced 3 times $(5.38 \%)$ by the Iranian EFL learners. The statements in this category simply reflect the learners' expression of condolence without any extra expressions of feeling, gratitude, or respect. What follows are some examples of this category:

- My condolences...

- Please accept my condolence

Expression of sarcasm was another strategy employed by Iranian EFL learners in which they showed their sarcasm and humor along with the expression of condolence. This strategy was used twice (3.50\%) and the following are the two examples of this category of condolence strategy.

- How come he still releases new song tracks?!

- NECROLATRY!!!!!

The first example above is a clear example of humor as the person is no longer alive and cannot release a new song. Regarding the second example (NECROLATRY!!!!!), the person is making a sarcastic utterance which means that people respect and adore a person after he is gone while they could recognize him and his works better during his life.

Statement about life and death and Expression of shock were the last condolence strategies used by the Iranian EFL learners. Both of these strategies had a frequency count of $n=1(1.75 \%)$. In the statement about life strategy, the learner expresses his anger toward the bad events and experiences of life.

- F--k cancer any way!

As the example above shows, the person used a slang word to show his disrespect and dissatisfaction with certain events of life, in this case cancer. In the Expression of shock strategy, it can be seen that the EFL learner just stated that he/she is still in shock because of Morteza's death.

- So young! 
In the example above, it is meant that he/she cannot believe that Morteza died so early in his life and he/she is shocked. The use of the exclamation mark also puts more emphasis on this state of surprise and shock.

\subsection{Results of research question two}

The second research question sought to explore any significant differences in the strategies used by the native speakers of Persian, the native speakers of English and the Iranian EFL learners in their production of the speech act of condolence in a computer-mediated social network. To provide statistical evidence for any significant differences among the participants, the frequency counts of data were analyzed using the statistical test of chi-square. Due to the fact that each statistical test requires certain assumptions prior to its employment, an alternative test was also utilized to detect the differences between the groups in terms of condolence strategy use. According to Yates, Moore, and McCabe (1999, p. 734) chi-square assumes that "No more than $20 \%$ of the expected counts are less than 5 and all individual expected counts are 1 or greater". In case the chi-square assumptions were violated in the following analysis, Likelihood Ratio was reported which is more common for comparison across three groups. Table 10 depicts the results of chi-square and Likelihood Ratio on frequency count of condolence strategies between the native Persian speakers, the native English speakers, and the Iranian EFL learners.

Table 10

Results of Chi-square Test on frequency count of condolence strategies between native Persian speakers, Iranian EFL learners, and English speakers

\begin{tabular}{|l|c|c|c|c|c|}
\hline \multicolumn{1}{|c|}{ Condolence Strategy } & Chi-Square Test & Value & df & $\begin{array}{c}\text { Asymp. Sig. } \\
\text { (2-sided) }\end{array}$ & $\begin{array}{c}\text { Chi-square } \\
\text { Cell } \\
\text { assumption }\end{array}$ \\
\hline Expression of affection (love and grief) & Pearson Chi-Square & $28.666 a$ & 2 & .000 & \\
\hline Wishes for the deceased & Pearson Chi-Square & $49.530 a$ & 2 & .000 & \\
\hline Expression of shock & Pearson Chi-Square & $24.978 \mathrm{a}$ & 2 & .000 & \\
\hline Use of address terms & Pearson Chi-Square & $49.259 \mathrm{a}$ & 2 & .000 & \\
\hline $\begin{array}{l}\text { Allusion to religious and metaphoric } \\
\text { concepts }\end{array}$ & Likelihood Ratio & 4.784 & 2 & .091 & Violated \\
\hline Expression of gratitude & Pearson Chi-Square & $78.236 a$ & 2 & .000 & \\
\hline Offering condolences & Likelihood Ratio & 8.738 & 2 & .013 & Violated \\
\hline $\begin{array}{l}\text { Expressofion happiness for his peaceful } \\
\text { death }\end{array}$ & Likelihood Ratio & 14.815 & 2 & .001 & Violated \\
\hline 'Seeking absolution from God' & Likelihood Ratio & 14.815 & 2 & .001 & Violated \\
\hline Statement about life and death & Likelihood Ratio & 3.649 & 2 & .161 & Violated \\
\hline Expression of shock & Likelihood Ratio & 3.649 & 2 & .161 & Violated \\
\hline
\end{tabular}

According to the results of Chi-square and Likelihood Ratio, there were significant differences among native Persian speakers, Native English speakers, and Iranian EFL learners in terms of use of condolence strategies in Expressing affection (love and grief) $\left(\mathrm{X}^{2}(2)=28.666, \mathrm{p}<.05\right)$, Wishes for the deceased 
$\left(\mathrm{X}^{2}(2)=49.530, \mathrm{p}<.05\right)$, Expression of shock $\left(\mathrm{X}^{2}(2)=24.978, \mathrm{p}<.05\right)$, Use of address terms $\left(\mathrm{X}^{2}(2)=49.259, \mathrm{p}<.05\right)$, Expression of gratitude $\left(\mathrm{X}^{2}(2)=78.236\right.$, $\mathrm{p}<.05)$, Offering condolences $\left(\mathrm{X}^{2}(2)=8.73, \mathrm{p}<.05\right)$, Expression of happiness for his peaceful death $\left(\mathrm{X}^{2}(2)=14.815, \mathrm{p}<.05\right)$, , and Seeking absolution from God $\left(\mathrm{X}^{2}(2)=14.815, \mathrm{p}<.05\right)$ categories. However, no significant difference was observed with regard to the categories of Allusion to religious and metaphoric concepts, Statements about life and death and Expression of shock.

Since the results of these tests only determine the statistical difference across the three group (native Persian speakers, Native English speakers, and Iranian EFL learners), one cannot decide where between the three groups the differences exactly lie. To find the exact place of difference between each two groups, Chi-square multiple contrasts were run. In case Chi-square assumptions were violated the results of Fishers Exact Test which is more common for comparisons between two groups were utilized. Table 11 displays the results of multiple contrasts frequency count of Expression of affection (love and grief), Wishes for the deceased, Expression of shock, Use of address terms, Expression of gratitude, Offering condolences, Expression of happiness for his peaceful death, and Seeking absolution from God categories to understand where the difference among native Persian speakers, English Speakers, and Iranian EFL learners exist.

Table 11

Results of Chi-square Between the Groups in Terms of Condolence Strategy Use

\begin{tabular}{|c|c|c|c|c|c|c|}
\hline $\begin{array}{c}\text { Condolence } \\
\text { strategy }\end{array}$ & Groups & Chi-Square Tests & Value & Df & \begin{tabular}{|c|} 
Asymp. Sig. \\
(2-sided)
\end{tabular} & $\begin{array}{c}\text { Assumption } \\
\text { violation }\end{array}$ \\
\hline \multirow{3}{*}{$\begin{array}{l}\text { Expression of } \\
\text { affection (love } \\
\text { and grief) }\end{array}$} & EFL vs Persian speakers & Pearson Chi-Square & $27.776 a$ & 1 & .000 & \\
\hline & \begin{tabular}{|l|} 
Persian speakers vs \\
English Speakers \\
\end{tabular} & Pearson Chi-Square & $3.57 a$ & 1 & .059 & \\
\hline & EFL vs English Speakers & Pearson Chi-Square & $9.14 a$ & 1 & .003 & \\
\hline \multirow{3}{*}{$\begin{array}{l}\text { Wishes for the } \\
\text { deceased }\end{array}$} & EFL vs Persian speakers & Pearson Chi-Square & $29.09 a$ & 1 & .000 & \\
\hline & \begin{tabular}{|l|} 
Persian speakers vs \\
English Speakers
\end{tabular} & Pearson Chi-Square & $34.98 a$ & 1 & .000 & \\
\hline & EFL vs English Speakers & Pearson Chi-Square & $.18 a$ & 1 & .670 & \\
\hline \multirow{4}{*}{$\begin{array}{l}\text { Expression of } \\
\text { shock }\end{array}$} & EFL vs Persian speakers & Pearson Chi-Square & $11.81 \mathrm{a}$ & 1 & .001 & \\
\hline & \begin{tabular}{|l|} 
Persian speakers vs \\
English Speakers
\end{tabular} & Pearson Chi-Square & $14.37 a$ & 1 & .000 & \\
\hline & \multirow[t]{2}{*}{ EFL vs English Speakers } & Pearson Chi-Square & $1.01 a$ & 1 & .315 & \multirow[t]{2}{*}{ Violated } \\
\hline & & \multicolumn{3}{|l|}{ Fisher's Exact Test } & 1.000 & \\
\hline \multirow{3}{*}{$\begin{array}{l}\text { Use of address } \\
\text { terms }\end{array}$} & EFL vs Persian speakers & Pearson Chi-Square & $.965 a$ & 1 & .326 & \\
\hline & \begin{tabular}{|l|} 
Persian speakers vs \\
English Speakers \\
\end{tabular} & Pearson Chi-Square & $41.24 a$ & 1 & .000 & \\
\hline & EFL vs English Speakers & Pearson Chi-Square & $25.20 \mathrm{a}$ & 1 & .000 & \\
\hline \multirow{4}{*}{$\begin{array}{l}\text { Expression of } \\
\text { gratitude }\end{array}$} & \multirow[t]{2}{*}{ EFL vs Persian speakers } & Pearson Chi-Square & $9.06 a$ & 1 & .003 & Violated \\
\hline & & \multicolumn{3}{|l|}{ Fisher's Exact Test } & .009 & \\
\hline & \begin{tabular}{|l|} 
Persian speakers vs \\
English Speakers \\
\end{tabular} & Pearson Chi-Square & $79.31 a$ & 1 & .000 & \\
\hline & EFL vs English Speakers & Pearson Chi-Square & $14.27 a$ & 1 & .000 & \\
\hline
\end{tabular}


Minoo Alemi et al. 2021. Russian Journal of Linguistics 25 (2). 417-442

\begin{tabular}{|c|c|c|c|c|c|c|}
\hline $\begin{array}{c}\text { Condolence } \\
\text { strategy }\end{array}$ & Groups & Chi-Square Tests & Value & Df & \begin{tabular}{|c|} 
Asymp. Sig. \\
(2-sided)
\end{tabular} & $\begin{array}{c}\text { Assumption } \\
\text { violation }\end{array}$ \\
\hline \multirow{6}{*}{$\begin{array}{l}\text { Offering } \\
\text { condolences }\end{array}$} & \multirow[t]{2}{*}{ EFL vs Persian speakers } & Pearson Chi-Square & $8.01 a$ & 1 & .005 & Violated \\
\hline & & \multicolumn{3}{|l|}{ Fisher's Exact Test } & .024 & \\
\hline & \multirow{2}{*}{$\begin{array}{l}\text { Persian speakers vs } \\
\text { English Speakers }\end{array}$} & Pearson Chi-Square & $8.01 a$ & 1 & .005 & Violated \\
\hline & & \multicolumn{3}{|l|}{ Fisher's Exact Test } & .024 & \\
\hline & \multirow[t]{2}{*}{ EFL vs English Speakers } & Pearson Chi-Square & $.000 a$ & 1 & 1.000 & \multirow[t]{2}{*}{ Violated } \\
\hline & & Fisher's Exact Test & & & 1.000 & \\
\hline \multirow{5}{*}{$\begin{array}{l}\text { Expression of } \\
\text { happiness for } \\
\text { his peaceful } \\
\text { death }\end{array}$} & EFL vs Persian speakers & \multicolumn{5}{|c|}{ No occurrence of this strategy was found } \\
\hline & \multirow{2}{*}{\begin{tabular}{|l|} 
Persian speakers vs \\
English Speakers
\end{tabular}} & Pearson Chi-Square & $16.85 \mathrm{a}$ & 1 & .000 & Violated \\
\hline & & \multicolumn{3}{|l|}{ Fisher's Exact Test } & .001 & \\
\hline & \multirow[t]{2}{*}{ EFL vs English Speakers } & Pearson Chi-Square & $4.174 a$ & 1 & .041 & Violated \\
\hline & & \multicolumn{3}{|l|}{ Fisher's Exact Test } & .117 & \\
\hline \multirow{5}{*}{$\begin{array}{l}\text { Seeking } \\
\text { absolution } \\
\text { from God }\end{array}$} & EFL vs Persian speakers & \multicolumn{5}{|c|}{ No occurrence of this strategy was found } \\
\hline & \multirow{2}{*}{\begin{tabular}{|l} 
Persian speakers vs \\
English Speakers \\
\end{tabular}} & Pearson Chi-Square & $16.856 a$ & 1 & .000 & Violated \\
\hline & & \multicolumn{3}{|l|}{ Fisher's Exact Test } & .001 & \\
\hline & \multirow[t]{2}{*}{ EFL vs English Speakers } & Pearson Chi-Square & $4.174 a$ & 1 & .041 & Violated \\
\hline & & \multicolumn{3}{|l|}{ Fisher's Exact Test } & .117 & \\
\hline
\end{tabular}

Generally, it was found that in the strategies Expression of affection (love and grief), Wishes for the deceased, Expression of shock, Use of address Terms, Expression of gratitude, Offering condolences, Expression of happiness for his Peaceful Death, and Seeking absolution from God categories, significant differences existed among Persian speakers, Native English speakers, and Iranian EFL learners. Multiple contrast indicated that the differences in Expressing affection (love and grief) and Expression of gratitude existed between all the groups i.e. EFL learners vs. Persian speakers, Persian speakers vs. English speakers, and EFL learners vs. Native English speakers while in the rest of aforementioned strategies differences existed in some pairs of the groups rather than all pairs of the groups.

For instance, in the category Expression of affection (love and grief), the difference lay between EFL learners vs. Persian speakers $\left(\mathrm{X}^{2}(1)=27.77, \mathrm{p}<0.05\right)$ and between EFL learners vs. native English speakers $\left(X^{2}(1)=9.14, p<0.05\right)$ while the difference between Persian speakers vs. native English speakers was nonsignificant $\left(\mathrm{X}^{2}(1)=3.57, \mathrm{p}>0.05\right)$. Regarding the category of Wishes for the deceased a significant difference was found between EFL learners vs. Persian speakers $\left(X^{2}(1)=29.09, p<0.05\right)$ and between Persian speakers vs. English Speakers $\left(X^{2}(1)=34.98, p<0.05\right)$. However, the difference between EFL learners vs. English Speakers was non-significant $\left(\mathrm{X}^{2}(1)=0.18, \mathrm{p}>0.05\right)$. It needs to be noted that, regarding the contrast between the three groups, in cases where none of the participants produced any strategy related to the relevant category no statistical test was run.

\section{Discussion}

The main objective of the present study was to shed light on the use of the speech act of condolence by three different groups of participants, namely, Iranian 
native Persian speakers, native English speakers, and Iranian EFL learners in a computer-mediated social network. Overall, the results indicated that there were both similarities and differences among the three groups. Moreover, in terms of theory, the results of the current study support Hymes's (1972) theory of communicative competence and bring the interrelationship between language and contextual issues to the fore. To be more specific, the theory of communicative competence deals with issues such as speech situation, speech event, speech act, and components of speech events.

Moreover, the theory of pragmatic competence which is regularly associated with Morris (1938) and Grice (1975) supports the findings of the present study. Pragmatics highlights the role of social context and social meaning of utterances and move away from the linguistic meaning. According to the pragmatics, speakers of various communities encapsulate their meanings through different patterns of language use. In line with these theories, the differences in condolence strategies used by the participants of this study can be linked to their various cultural norms. Discrepancies in cultural norms could have forced them to produce a wide range of strategies with different frequencies. However, it needs to be noted that the results of our study showed both similarities and differences among the participants with regard to different condolence strategy types.

Concerning the first research question and the type of condolence strategies used by native speakers of Persian, Iranian EFL learners, and native English speakers in a computer-mediated social network, the responses to an updated death announcements on Instagram led to a corpus of various condolence strategies. The corpus was content analyzed and consequently different categories of condolence strategies were identified by the participants. Similarities existed among the three groups in terms of use of condolence strategies, an example of which was wishes for the deceased. This condolence strategy was among the most common strategy types used by native speakers of English, native speakers of Persian, and Iranian EFL learners. On the other hand, the strategy of offering condolences was among the least common strategies used by the three groups in this study. Such similarities can be attributed to the international stance of present societies (Ushioda 2006, Yashima 2002) or the shared cultural knowledge across various societies due to interactions mediated through mass media and the internet. Moreover, although there are various cultural norms in the world, there are still common grounds observed in all societies. We are all human and as part of humanistic characteristics, affect is the one shared by all people of the world. Therefore, it is not unexpected to witness similarities in condolence expression by various cultures as this speech act is tied to affect and sympathy (Yahia 2010).

The findings of the present study are in line with those from Samavarchi and Allami's (2012) study on the speech act of giving condolences by the EFL learners in Iran. In this study, the data were collected through 15-item Discourse Completion Task (DCT) from 10 native speakers of English and 50 Iranian EFL learners who also completed the Persian version of the DCT. Their results showed significant 
differences among the participants. Nevertheless, the results also showed that some EFL learners used the speech act of condolence in a similar way to the native English speakers. Moreover, in terms of categories of condolence strategies, there were great similarities between the three groups. For instance, the categories Wishes for the deceased, Use of address terms, Expression of gratitude, Expression of affection, and Expression of condolence were all common across the three groups; though the frequency of use was different. Similarly, studies by Elwood (2004), Yahia (2010), Lotfollahi and Rasekh (2011), as well as Olshtain and Cohen (1983) identified similar categories of Acknowledgement of the death, Expression of sympathy, Offer of assistance like, Future-oriented remarks such, and Expression of concern in various contexts in investigating the expression of condolence.

Our results are also in tandem with Al-Shboul and Maros (2013) who also reported of some similar condolence strategies from among 678 posted comments on Facebook in Jordanian Arabic, such as praying for God's forgiveness, reading Quranic verses, expressing shock and grief, as well as offering condolences. By contrast, some condolence strategies were not in line with the current study, such as enumerating the features of the dead, stating that death is natural, and the use of proverbs in condolence.

However, our findings are not in consonance with that of Wakefield, Chor and Lai (2020) who found that for English native speakers the main focus was on expressing grief for a person's death. By contrast, the current study revealed that the main condolence strategy used by native English speakers was expressing good wishes for the deceased. The present study's findings are also not totally in line with Nurlianingsih and Imperiani (2020). To be more specific, although seeking absolution from God was among the observed condolence strategies in this study, it was not ranked the first in any of the groups. This is however in contrast with Nurlianingsih and Imperiani (2020) who reported that Indonesian speakers mostly use this condolence strategy, seeking absolution from God, in their talks.

Moreover, the second research question sought to investigate the existence of any significant difference in the strategies used by native speakers of English, native speakers of Persian, and Iranian EFL learners in their production of the speech act of condolences in a computer-mediated social network. The results of the statistical analysis showed that there were significant differences among the three groups in terms of the use condolence strategies in Expression of affection (love and grief), Wishes for the deceased, Expression of shock, Use of address terms, Expression of gratitude, Offering condolences, Expression of happiness for his peaceful death, and Seeking absolution from God categories. Previous empirical studies also support the present findings regarding these differences. For instance, Lotfollahi and Rasekh (2011) examined the discrepancies in the production of the condolence speech act in English and Persian with a focus on the cross-cultural differences. Their results indicated that religion was the influential factor in shaping condolence strategies used by Persians. Moreover, Pishghadam and Morady Moghadam (2012) studied the condolence strategies used in English and Persian and found that Persian 
condolences had religious and spiritual root while English condolences were more materialistic.

As discussed earlier, such differences in the use of speech acts can be attributed to differences in the conceptualization and verbalization in different cultures and languages (Green 1975, Wierzbicka 1985) and also the interactional function of language (Yule 1985). Accordingly, it is quite sensible to expect differences in condolence strategies in various cultures. Iranian EFL learners are also affected by both the native culture and the target culture and therefore, it is not unexpected to witness differences in condolence strategies used by them compared to both native English speakers and native Persian speakers.

\section{Conclusion and implication}

The present study was set to investigate the offering of death-related condolence among the three groups of Iranian native speakers of Persian, American native speakers of English, and Iranian EFL learners in the context of the social media of Instagram. The findings proved both similarities and differences among the participants in terms of the use of condolence strategies. On the one hand, due to the fact that a social event such as condolence is shaped by the cultural norms of societies, it is quite common to expect differences in condolence strategies across cultures. On the other hand, because of globalization and international posture and also because of certain inherent characteristics of all human beings such as affect, observing some similarities in condolence strategies was acceptable and expected.

The results of the present study suggest certain implications for EFL teachers, syllabus designers, as well as educational materials developers. For one thing, the intricate interrelation between language and culture cannot be denied. This brings the necessity of enhancing the cross-cultural awareness to the limelight (EslamiRasekh \& Mardani 2010, Spencer-Oatey 2008). The authors of the current study would like to conclude that direct teaching of speech acts needs to be taken more seriously if it is aimed to prevent future pragmatic failures of the EFL learners. As Jawad (2021) argues the previous studies on pragmatic acquisition show that many students experience difficulty in the production of different speech acts, such as condolence giving, which may be due to "the students' incompetence to identify the proper meaning and to handle the proper form $<\ldots>$ Socio-pragmatic deviation occurs because they are linguistically unconscious of the conventions and means used in the target language" (p. 3497). To put it differently, language students need something more than a mere knowledge of grammar and vocabulary. The learners need to be equipped with wider knowledge on certain social standards and conventions.

Since the study showed that there were differences in some categories of condolence strategies among the participants, language teachers are cautioned about the negative pragmatic transfer when teaching English speech acts to Iranian EFL learners. Learners need to explicitly be made aware of the cross-cultural differences regarding the production of condolence and its significance in the 
establishment of successful communication. Similarly, syllabus designers and materials developers should take this into account and look for the best ways grounded in empirical research to provide materials for teaching condolence strategies to Iranian EFL learners. The students' familiarity with such differences in expressing condolence in English may be the initial step in raising students' consciousness about speech act performance in English.

(C) Minoo Alemi, Niayesh Pazoki Moakhar and Atefeh Rezanejad, 2021
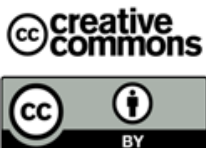

This work is licensed under a Creative Commons Attribution 4.0 International License https://creativecommons.org/licenses/by/4.0/

\section{REFERENCES}

Abdul-Majid, Mohammed Safwat \& Ahmed Mohammed, Salih. 2019. A cross-cultural study speech act of condolence in English and Arabic. Journal of Al-Frahedis Arts 11 (38). 544-568.

AbuSeileek, Ali F. 2013. Using track changes and word processor to provide corrective feedback to learners in writing. Journal of Computer Assisted Learning 29 (4). 319-333.

Ajabshir Zahra F. 2019. The effect of synchronous and asynchronous computer-mediated communication (CMC) on EFL learners' pragmatic competence. Computers in Human Behavior 92. 169-177. DOI: https://doi.org/10.1016/j.chb.2018.11.015

Al-Shboul, Yasser \& Marlyna Maros. 2013. Condolences strategies by Jordanians to an obituary status update on Facebook. GEMA Online Journal of Language Studies 13 (3). $151-162$.

Austin, John Langshaw. 1962. How to Do Things with Words. Oxford: Oxford University Press. Bachman, Lyle F. 1990. Fundamental Considerations in Language Testing. Oxford University Press.

Bardovi-Harlig, Kathleen. 2013. Developing L2 pragmatics. Language Learning 63 (1). 68-86.

Blum-Kulka, Shoshana. 1991. Interlanguage pragmatics: The case of requests. Foreign/second language pedagogy research. 255-272.

Elwood, Kate. 2004. I'm so sorry: A cross-cultural analysis of expressions of condolence. The Cultural Review 24. 101-126. Retrieved from http://dspace.wul.waseda.ac.jp/dspace/ handle $/ 2065 / 6087$ ?Mode $=$ full

Eslami-Rasekh, Abbass \& Mehdi Mardani. 2010. Investigating the effects of teaching apology speech act, with a focus on intensifying strategies, on pragmatic development of EFL learners: The Iranian context. The International Journal of Language Society and Culture 30 (1). 96-103.

Green, Georgia M. 1975. How to get people to do things with words: The whimperative question. In P. Cole \& J. Morgan (eds.), Syntax and semantics: Speech acts, 41-58. New York: Brill.

Grice, Herbert P. 1975. Logic and conversation. In P. Cole \& J. Morgan (eds.), Syntax and semantics: Speech acts, 41-58. New York: Brill.

Hymes, Dell. 1967. The anthropology of communication. In F. Dance (ed.), Human communication theory, 1-39. New York: Holt, Rinehart and Winston. 
Jawad, Kamal H. 2021. Condolence in classroom teaching: Iraqi EFL university students' pragmatic deviation. Psychology and Education 58 (1). 3497-3508.

Kasper, Gabriele \& Merete Dahl. 1991. Research methods in interlanguage pragmatics. Studies in second language acquisition 13 (02). 215-247.

Kasper, Gabriele \& Kenneth R. Rose (eds.). 2001. Pragmatics in Language Teaching. Germany: Ernst Klett Sprachen.

Lotfollah, Bahareh \& Abbass Eslami-Rasekh. 2011. Speech act of condolence in Persian and English. Studies in Literature and Language 3 (3). 139-145.

Morris, Charles William. 1938. Foundations of the theory of signs. In O. Neurath, R. Carnap \& C. Morris (eds.), International Encyclopedia of Unified Science, 77-138. Chicago: University of Chicago Press.

Mwihaki, Alice. 2004. Meaning as use: A functional view of semantics and pragmatics. Swahili Forum 11 (1). 127-139.

Nurlianingsih, Diah \& Ernie D. A. Imperiani. 2020. An Analysis of Condolences Speech Act by Indonesian Adolescents. In Twelfth Conference on Applied Linguistics (CONAPLIN 2019). 34-38. Atlantis Press.

Olshtain, Elite \& Andrew D. Cohen. 1983. Apology: A speech act set. In N. Wolfson and E. Judd (eds.), Sociolinguistics and Language Acquisition, 18-35. Rowley, MA: Newbury House.

Parkes, Colin Murray. 2015. Help for the dying and the bereaved. In Colin Murray Parkes, P. Laungani, \& B. Young (eds.), Death and bereavement across cultures. 166-177. New York: Routledge.

Pavlovskaya, Galina \& Anastasia Lord. 2018. The Influence of students' sociocultural background on the IELTS speaking test preparation process. Journal of Language and Education 4 (3). 69-76. DOI: https://doi.org/10.17323/2411-7390-2018-4-3-69-76

Pishghadam, Reza \& Mostafa Morady Moghaddam. 2013. Investigating condolence responses in English and Persian. International Journal of Research Studies in Language Learning 2 (1). 39-47.

Samavarchi, Laila \& Hamid Allami. 2012. Giving condolences by Persian EFL learners: A contrastive sociopragmatic study. International Journal of English Linguistics 2 (2). $71-78$.

Searle, John. R. 1969. Speech Acts: An Essay in the Philosophy of Language. Cambridge: Cambridge University Press.

Shively, Rachel L. 2010. From the virtual world to the real world: A model of pragmatics instruction for study abroad. Foreign Language Annals 43 (1). 105-137.

Spencer-Oatey, Helen. 2008. Culturally Speaking: Culture, Communication and Politeness Theory. 2nd edn. Bloomsbury Publishing.

Taguchi, Naoko. 2011. Teaching pragmatics: Trends and issues. Annual Review of Applied Linguistics 31 (1). 289-310.

Thomas, Jenny. 1983. Cross-cultural pragmatic failure. Applied Linguistics 4 (2). 91-112.

Ushioda, Ema. 2006. Language motivation in a reconfigured Europe: Access, identity and autonomy. Journal of Multilingual and Multicultural Development 27 (2). 148-161.

Utama, Sekar Hapsari Puja \& Siti Zuhriyah Ariatmi. 2020. Condolence Expression Used by Social Media Users for the Passing of Kobe Bryant and His Daughter Gianna. Unpublished Doctoral dissertation, Universitas Muhammadiyah Surakarta.

Vygotsky, Lev. S. 1978. Socio-cultural theory. Mind in society. 52-58.

Wakefield, John C., Winnie Chor \& Nikko Lai. 2020. Condolences in Cantonese and English: What people say and why. In K. Mullan, B. Peeters, \& L. Sadow (eds.), Studies in ethnopragmatics, cultural semantics, and intercultural communication, 35-58. Singapore: Springer. 
Wierzbicka, Anna. 1985. Different cultures, different languages, different speech acts: Polish vs. English. Journal of pragmatics 9 (2-3). 145-178.

Yahia, Ebaa M. 2010. A study of condolences in Iraqi Arabic with reference to English. Adab Al-Rafidayn 57. 47-70.

Yashima, Tomoko. 2002. Willingness to communicate in a second language: The Japanese context. Modern Language Journal 86 (1). 54-66.

Yule, George. 1996. Pragmatics. Oxford: Oxford University Press.

\section{Article history:}

Received: 26 September 2020

Accepted: 15 March 2021

\section{История статьи:}

Дата поступления в редакцию: 26 сентября 2020

Дата принятия к печати: 15 марта 2021

\section{Bionotes:}

Minoo ALEMI is an Associate Professor of Applied Linguistics at IAU, West Tehran Branch, and a research associate at Sharif University of Technology (SUT), Iran. Her areas of interest include L2 pragmatic instruction \& assessment, technology enhancement education, teacher education, discourse analysis, and ESP (English for Specific Purposes). She has also published over 100 papers in different refereed journals, and two book chapters in the volume Lessons from Good Language Teachers (Cambridge University Press, 2020). She is also the co-editor of Pragmatics Pedagogy in English as an International Language (Routledge, 2020).

\section{Contact information:}

Islamic Azad University, West Tehran Branch

Tehran, Iran

e-mail: minooalemi2000@yahoo.com

ORCID: 0000-0001-9703-831X

Niayesh PAZOKI MOAKHAR is a Ph.D. student in Educational Psychology at Simon Fraser University, Canada. Her main research interest centers on refugees with special needs and their educational experiences in everyday life. She also studies multiculturalism and language diversification in refugee studies due to her previous educational background in Applied Linguistics.

\section{Contact information:}

Simon Fraser University

Burnaby, Canada

e-mail:npazokim@sfu.ca

Atefeh REZANEJAD is a Ph.D. holder in Applied Linguistics from Allameh Tabataba'i University, Tehran, Iran. She has been teaching various university courses in applied linguistics since 2003. Her areas of interest include intercultural language learning, pragmatics, teacher education, and sociolinguistics.

\section{Contact information:}

Allameh Tabataba'i University

Tehran, Iran

e-mail: rezanejad_a85@yahoo.com

ORCID: 0000-0002-3271-4273 


\section{Сведения об авторах:}

Мину АЛЕМИ - доцент Западно-Тегеранского отделения Исламского университета Азад, научный сотрудник Технологического университета им. Шарифа (Иран). Специализируется в области прикладной лингвистики. В сферу eе научных интересов входят преподавание иностранного языка, технология оптимизации образования, педагогическое образование, дискурс-анализ и английский для специальных целей. Она является автором более 100 статей в научных рецензируемых журналах, двух глав в книге Lessons from Good Language Teachers (Cambridge University Press, 2020), а также соредактором издания Pragmatics Pedagogy in English as an International Language (Routledge, 2020).

\section{Контактная информация:}

Islamic Azad University, West Tehran Branch

Tehran, Iran

e-mail: minooalemi2000@yahoo.com

ORCID: 0000-0001-9703-831X

Нияеш ПАЗОКИ МОАХАР - аспирант Университета Саймона Фрейзера, занимается проблемами педагогической психологии. Ее научные интересы сосредоточены на беженцах с ограниченными возможностями здоровья. Она также изучает мультикультурализм и диверсификацию языков в среде беженцев, чему способствует ее образование в области прикладной лингвистики.

\section{Контактная информация:}

Simon Fraser University

Burnaby, Canada

e-mail:npazokim@sfu.ca

Атефех РЕЗАНЕЖАД - доктор прикладной лингвистики, Университет имени Алламе Табатабаи (Тегеран, Иран). С 2003 г. преподает различные курсы в сфере прикладной лингвистики. Ее научные интересы включают преподавание иностранных языков в межкультурном контексте, прагматику, педагогику и социолингвистику.

\section{Контактная информация:}

Allameh Tabataba'i University

Tehran, Iran

e-mail: rezanejad_a85@yahoo.com

ORCID: 0000-0002-3271-4273 